\title{
Karakter Disiplin, Penghargaan, dan Tanggung Jawab dalam Kegiatan Ekstrakurikuler
}

Andi Tenri Faradiba

Fakultas Psikologi, Universitas Pancasila, atenrifaradiba@univpancasila.ac.id

\section{Lucia R.M. Royanto}

Fakultas Psikologi, Universitas Indonesia

\begin{abstract}
ABSTRAK
Penelitian ini adalah penelitian deskriptif untuk mengetahui gambaran karakter disiplin, penghargaan, dan tanggung jawab dalam kegiatan ekstrakurikuler siswa SMA. Karakter adalah aspek-aspek kepribadian yang dipelajari melalui pengalaman, latihan, dan proses sosialisasi. Kegiatan ekstrakurikuler terbagi dalam lima kategori, yaitu kegiatan prososial, olahraga, seni, keterlibatan sekolah, dan kelompok akademik. Jumlah partisipan sebanyak 95 orang. Hasil penelitian ini menunjukkan adanya perbedaan yang signifikan antara karakter disiplin dalam lima kategori kegiatan ekstrakurikuler. Olahraga memiliki nilai rata-rata tertinggi untuk karakter disiplin dan penghargaan sedangkan kelompok akadamik memiliki nilai rata-rata tertinggi untuk karakter tanggung jawab.
\end{abstract}

Kata kunci: disiplin, penghargaan, tanggung jawab, kegiatan ekstrakurikuler

\section{ABSTRACT}

This research is a descriptive research which was held to describe discipline, respectful, and responsible characters of senior high school students who engage in extracurricular activities. Characters are personality aspects gained through experience, training, and socialization process. Extracurricular activities are divided into five different categories: prosocial, team sports, performing arts, school involvement, and academic clubs. Total participants were 95 students. The result shows that there is a significant difference among discipline character in those five extracurricular activities. Team sports category has the highest mean of discipline and respectful characters while academic club category has the highest mean for responsible character.

Keywords: discipline, respectful, responsible, extracurricular activity

Kesadaran akan pentingnya pendidikan karakter dirasakan di Indonesia. Adanya ketidaksesuaian yang terjadi antara harapan masyarakat dengan keadaan faktual menjadi salah satu alasannya. Harapan masyarakat adalah siswa memiliki pencapaian prestasi akademik diiringi peningkatan perilaku positif. Akan tetapi, fakta yang terjadi adalah adanya peningkatan perilaku negatif siswa. Peningkatan perilaku negatif menjadi tanda belum terwujudnya cita-cita pendidikan di Indonesia yang ingin membentuk peserta didik yang cerdas dan berkarakter.

Karakter tidak muncul begitu saja karena bukan sesuatu yang dimiliki sejak lahir. Karakter dibentuk sepanjang usia kehidupan terutama ketika masa anakanak dan remaja (Damon, 1988 dalam Berkowitz \& Bier, 2004). Lingkungan anak terutama lingkungan keluarga (Berkowitz \& Grych, 1998 dalam Berkowitz \& Bier, 2004) dan sekolah berperan penting dalam pembentukan karakter anak (Berkowitz \& Grych, 2000 dalam Berkowitz \& Bier, 2004). Kedua lingkungan tersebut harus saling mendukung dan bekerja sama dalam membentuk karakter untuk menghindari kebingungan dalam diri anak tentang perilaku yang berkarakter. Damon (1988 dalam Park,
2004) menyatakan bahwa orang tua berperan penting dalam perkembangan karakter anak terkait dengan pola asuh yang diterapkan. Dalam lingkungan sekolah, karakter dikembangkan melalui aktivitas pendidikan yang sengaja dirancang untuk membina karakter peserta didik melalui pendidikan karakter (Haricahyono 1995).

Penerapan pendidikan karakter dilakukan dengan pengintegrasian karakter ke dalam mata pelajaran, program pengembangan diri, dan budaya sekolah (Kemendiknas, 2010). Salah satu kegiatan yang termasuk di dalamnya adalah kegiatan ekstrakurikuler. Kegiatan ekstrakurikuler didefinisikan sebagai kegiatan bersama yang dilakukan di sekolah yang merupakan kegiatan tambahan dan bukan merupakan kegiatan utama serta memiliki tujuan jelas yang berguna bagi pengembangan siswa (Mahoney, 2002 dalam Mahoney, Larson, \& Eccles, 2005).

Penelitian ini lebih melihat perkembangan karakter di masa remaja khususnya siswa kelas 3 SMA. Perkembangan karakter di masa remaja lebih banyak dipengaruhi oleh lingkungan sekolah khususnya teman sebaya karena hal tersebut sesuai dengan karakteristik remaja yang menghabiskan 
waktu lebih banyak bersama teman sebaya. Penelitian ini ingin melihat peran kegiatan ekstrakurikuler dalam perkembangan karakter siswa karena remaja yang memiliki kemiripan akan saling memengaruhi untuk semakin mirip, seperti kemiripan minat dalam kegiatan ekstrakurikuler yang diikuti. Berbagai penelitian menyatakan keterlibatan siswa dalam kegiatan ekstrakurikuler memiliki hubungan positif dengan perkembangan karakter remaja, tetapi hal tersebut ditentukan oleh kegiatan yang diikuti. Oleh karena itu, penelitian ini ditujukan untuk melihat gambaran karakter siswa SMA dalam kegiatan ekstrakurikuler. Fokusnya hanya pada tiga karakter, yaitu disiplin, penghargaan, dan tanggung jawab. Lickona (1991) menyatakan bahwa ada dua karakter utama dalam agenda pendidikan karakter, yaitu tanggung jawab dan penghargaan. Selain itu, Durkheim (1961 dalam Haricahyono, 1995) menyebutkan disiplin sebagai karakter dasar yang harus dimiliki oleh peserta didik.

\section{Karakter Disiplin}

Disiplin adalah patuh pada peraturan yang berlaku dalam masyarakat baik peraturan ini merupakan Undang-Undang, adat kebiasaan maupun tata cara pergaulan lainnya. Menurut Wissow (2002 dalam Smith, 2004), disiplin adalah proses mengajarkan anak tentang nilai dan perilaku normatif dalam masyarakat. Menurut Smith (2004), disiplin terbagi atas dua, yaitu disiplin positif dan disiplin negatif. Disiplin positif mengajarkan anak memahami alasan suatu perilaku diperbolehkan dan perilaku yang lainnya dilarang sedangkan disiplin negatif hanya mengajarkan anak untuk patuh dan menghindarkan diri dari hukuman. Yang perlu dikembangkan adalah disiplin positif karena disiplin berbeda dengan menghindarkan diri dari hukuman (Holden, 2002 dalam Smith, 2004). Hubungan baik merupakan dasar dari membangun disiplin (Dodson, 2006). Hubungan baik yang dimaksud adalah saling menyenangi, menghormati, dan menanggapi dengan baik.

Guru dan orang tua diharapkan dapat membina hubungan baik terlebih dahulu dengan anak atau siswa agar dapat mengajarkan disiplin. Selain itu, pembentukan disiplin juga dipengaruhi oleh faktor eksternal, seperti lingkungan keluarga dan lingkungan sekolah. Smith (2004) menjelaskan pengaruh faktor eksternal dengan landasan teori ecological dari Bronfenbrenner (1979), yaitu keluarga sebagai mikrosistem pertama memberikan pengaruh besar dalam pembentukan kerangka disiplin anak yang dipengaruhi oleh sejarah keluarga, budaya, dan keyakinan dalam keluarga sedangkan sekolah sebagai mikrosistem kedua dapat memberikan pengaruh besar untuk mendukung atau merusak kemampuan keluarga dalam membangun disiplin bagi anak. Smith (2004) juga menjelaskan pembentukan disiplin yang didasari oleh teori sosiokultural, yaitu ketika siswa merasakan pengalaman sakit dan negatif dari guru, ia akan menginternalisasi pengalaman itu dalam berinteraksi dengan orang lain.

\section{Karakter Penghargaan}

Lickona (1991) mendefinisikan penghargaan sebagai memandang sesuatu atau seseorang sebagai hal yang berharga atau bernilai. Shockley (2009) menyatakan bahwa penghargaan adalah menganggap penting sesuatu atau seseorang yang berkaitan dengan nilai yang dilekatkan pada sesuatu atau seseorang tersebut. Lickona (1991) menyebutkan tiga dimensi penghargaan, yaitu penghargaan terhadap diri sendiri, penghargaan terhadap orang lain, dan penghargaan terhadap lingkungan dan kehidupan. Karakter penghargaan yang dikembangkan di sekolah dapat mencegah terjadinya tawuran, bullying, dan perilaku kejam siswa (Lickona, 1991).

Menurut Lickona (1991), lebih mudah mengembangkan karakter penghargaan ketika individu memiliki pengetahuan tentang hal yang ingin diberikan penghargaan baik terhadap dirinya, orang lain, maupun lingkungan dan kehidupan. Ketika individu memiliki pengetahuan, ia cenderung memiliki konsep nilai tersendiri yang akan dilekatkan pada sesuatu yang dihargai. Shockley (2009) menyatakan bahwa penghargaan dipengaruhi oleh konsep nilai yang dimiliki individu yang kemudian menuntunnya mengambil sikap.

\section{Karakter Tanggung Jawab}

Lickona (1991) menyatakan tanggung jawab sebagai bagian aktif dari moral yang terdiri dari menjaga diri sendiri dan orang lain, memenuhi kewajiban, memberikan kontribusi kepada masyarakat, mengurangi penderitaan, dan membangun dunia yang lebih baik. Faktor lingkungan memberikan pengaruh besar terhadap pembentukan tanggung jawab individu. Hal ini disebabkan oleh tanggung jawab yang bukan bawaan lahir dan tidak dimiliki secara alami oleh individu (Rich, 1992).

Tanggung jawab juga dapat dibentuk dengan membantu individu agar merasa memiliki kompetensi, mengetahui, dan melakukan hal yang harus dilakukan (Rich, 1992). Untuk itu, individu perlu diberikan tugas dan kewajiban yang menjadi tantangan bagi dirinya yang harus diselesaikan. 
Seringkali individu termotivasi untuk meningkatkan performanya karena diberikan suatu tanggung jawab yang baru (Rich, 1992).

\section{Kegiatan Ekstrakurikuler}

Mahoney (2002 dalam Mahoney, Larson, \& Eccles, 2005) mengelompokkan berbagai kegiatan ekstrakurikuler ke dalam lima kategori, yaitu:

a. Kegiatan prososial

Kegiatan ini bersifat melayani masyarakat dengan tujuan memberikan pencerahan dan motivasi kepada siswa, meningkatkan kecerdasan emosional dan kecerdasan spiritual siswa agar mampu menciptakan lingkungan yang efektif dan harmonis. Contoh kegiatan ini adalah kerohanian (remaja mesjid), Pramuka, dan Palang Merah Remaja.

b. Olahraga

Tujuan kegiatan ini adalah membina siswa menjadi sehat atau menjadikan lebih baik dari sebelumnya. Contoh kegiatan ini adalah sepak bola dan basket.

c. Seni

Tujuan kegiatan seni adalah memberikan kesempatan kepada siswa untuk terlibat dalam berbagai pengalaman apresiasi dan pengalaman berkreasi. Siswa berkreasi dalam menciptakan berbagai kesenian secara sistematis sehingga diperoleh pengalaman konseptual, pengalaman apresiatif, dan pengalaman kreatif. Contoh kegiatan ini adalah marching band, kreasi seni budaya, dan seni sastra.

\section{d. Keterlibatan sekolah}

Tujuan kegiatan ini adalah melatih kemampuan berorganisasi siswa dalam rangka melakukan kegiatan remaja yang positif, terarah, dan membina kelompok siswa menjadi siswa yang terdidik, berakhlak, dan berkarakter. Contoh kegiatan ini adalah OSIS, MPK, dan pemandu sorak.

e. Kelompok akademik

Tujuan kegiatan ini adalah mengembangkan sikap ilmiah dan kejujuran dalam memecahkan gejala alam maupun sosial yang ditemui dengan metode yang sistematis, objektif, rasional, dan berprosedur sehingga akan didapatkan kompetensi untuk mengembangkan diri dalam kehidupan. Contoh kegiatan ini adalah Kegiatan Ilmiah Remaja.

\section{METODE}

Berdasarkan tujuannya, penelitian ini tergolong dalam penelitian deskriptif dengan partisipan yaitu remaja kelas 3 SMA yang berdomisili di wilayah Jakarta dan mengikuti kegiatan ekstrakurikuler selama minimal 1 tahun. Keterlibatan siswa selama minimal satu tahun dalam kegiatan ekstrakurikuler diasumsikan mempengaruhi karakter yang dimiliki oleh siswa.

Teknik pengambilan sampel yang digunakan adalah accidental sampling. Teknik ini dipilih karena merupakan cara termudah dalam penyeleksian partisipan dan menjamin diperolehnya karakteristik partisipan yang dibutuhkan (Kumar, 2005). Adapun kelemahan metode ini adalah hasil yang diperoleh tidak dapat digeneralisir pada populasi secara keseluruhan dan adanya kemungkinan bahwa orang yang paling mudah dijangkau tidak benar-benar representatif untuk populasi (Kumar, 2005).

Alat ukur disiplin terdiri dari 24 item yang mengukur perilaku disiplin siswa di rumah, kelas, sekolah, dan masyarakat dengan nilai reliabilitas sebesar 0,75 . Pilihan respon menggunakan 4 poin skala Likert, tidak sesuai, agak tidak sesuai, agak sesuai, dan sesuai. Alat ukur penghargaan terdiri dari tiga dimensi, yaitu penghargaan terhadap diri sendiri, orang lain, dan lingkungan dan kehidupan yang terdiri dari 17 item dengan nilai reliabilitas 0,77. Alat ukur tanggung jawab terdiri dari enam dimensi, yaitu hasil yang bermutu, kesediaan menanggung risiko, pengikatan diri dalam tugas, memiliki prinsip hidup, kemandirian, dan keterikatan sosial yang berjumlah 37 item dengan nilai reliabilitas 0,91. Setelah data terkumpul, digunakan teknik statistik desktiptif untuk mengetahui mean, median, modus, standar deviasi, nilai minimum, dan nilai maksimum dari skor-skor yang diperoleh. Selain itu dilakukan pula uji ANOVA untuk menjawab masalah penelitian mengenai perbedaan nilai mean karakter disiplin, penghargaan, dan tanggung jawab dalam lima kategori kegiatan ekstrakurikuler.

\section{HASIL DAN PEMBAHASAN}

Jumlah partisipan adalah 95 siswa kelas 3 SMA berusia rata-rata 17 tahun. Dari 95 siswa, ada 47 yang mengikuti 1 kegiatan ekstrakurikuler, 34 mengikuti 2 kegiatan, dan 14 siswa mengikuti 3 kegiatan. Tabel 1 menunjukkan jumlah siswa di setiap kegiatan ekstrakurikuler yang diikuti. Tabel 2 menjabarkan nilai mean karakter disiplin dan penghargaan yang paling tinggi adalah kegiatan olahraga, sedangkan nilai mean karakter tanggung jawab yang paling tinggi adalah kelompok akademik. Tabel 2 juga menunjukkan bahwa karakter disiplin memiliki nilai $\mathrm{F}=3,032$ dengan level of significant $(\mathrm{p}<0,05)$, artinya terdapat perbedaan karakter disiplin yang signifikan antara lima kategori kegiatan ekstrakuikuler. Untuk karakter penghargaan, nilai F
Kommentar [is2]: Sebutkan daerah

smanya 
sebesar 2,203 dengan level of significant ( $>>0,05)$, artinya tidak terdapat perbedaan karakter penghargaan yang signifikan antara lima kategori kegiatan ekstrakurikuler. Karakter tanggung jawab memiliki nilai $\mathrm{F}$ sebesar 0,371 dengan level of significant $(\mathrm{p}>0,05)$, artinya tidak terdapat perbedaan karakter tanggung jawab antara lima kategori kegiatan ekstrakurikuler

Tabel 1 Kategori jenis kegiatan ekstrakurikuler

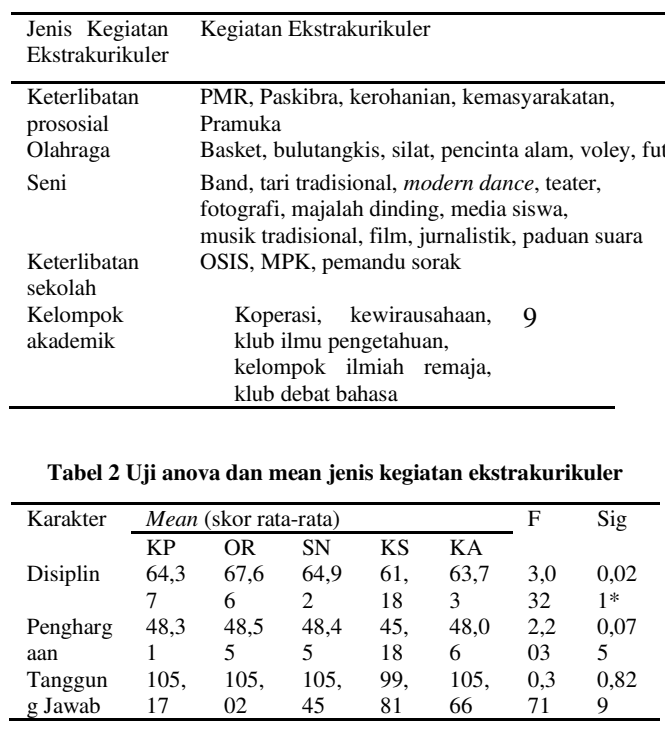

Untuk mengetahui lebih jauh mengenai perbandingan karakter disiplin dalam setiap kategori kegiatan ekstrakurikuler, dilakukan uji Pots-Hoc yang ditunjukkan pada tabel 3. Hasilnya menunjukkan bahwa tidak ada kategori kegiatan ekstrakurikuler yang memiliki karakter disiplin yang lebih tinggi dibandingkan kategori kegiatan ekstrakurikuler yang lain.

Tabel 3 Uji post-hoc karakter disiplin

\begin{tabular}{llllll}
\hline Jenis & \multicolumn{5}{l}{ Jenis Kegiatan Ekstrakurikuler (sig) } \\
\cline { 2 - 6 } Keg.Ekskul & KP & OR & SN & KS & KA \\
\hline KP & - & 0,778 & 0,217 & 0,451 & 0,927 \\
OR & 0,778 & - & 0,889 & 0,951 & 0,427 \\
SN & 0,217 & 0,889 & - & 1 & 0,108 \\
KS & 0,491 & 0,991 & 1 & - & 0,242 \\
KA & 0,927 & 0,427 & 0,108 & 0,242 & - \\
\hline
\end{tabular}

Perbedaan karakter disiplin, penghargaan, dan tanggung jawab dalam kegiatan ekstrakurikuler siswa SMA diketahui dari hasil perbandingan nilai mean masing-masing kategori kegiatan ekstrakurikuler. Untuk karakter disiplin, hasil yang ditunjukkan adalah terdapat perbedaaan signifikan dalam lima kategori kegiatan ekstrakurikuler. Artinya, terdapat perbedaan karakter disiplin antara siswa-siswa yang berbeda kategori kegiatan ekstrakurikulernya. Setiap kegiatan ekstrakurikuler menerapkan aturan yang wajib dipatuhi oleh setiap anggotanya. Aturan yang dibuat mengandung kejelasan tentang perilaku yang diharapkan dari setiap anggota dan konsekuensi yang diberikan ketika tidak dilakukan. Akan tetapi, pelaksanaan aturan tersebut berbeda antar setiap Jumlahstrakurikuler. Untuk kategori kegiatan olahragaa yang memiliki nilai mean tertinggi, aturan yang 2 fiburat dijalankan secara konsisten karena kegiatan ini mengutamakan kepatuhan anggotanya têrhadૈ atp aturan. Berbeda dengan kegiatan seni yang memiliki nilai mean terendah yang tujuan utamanya adalah memberikan pengalaman apresiasi dan pengdlaman berkreasi bagi siswa. Untuk menghasilkan kreasi membutuhkan kreativitas yang tidak dapat dikontrol kemunculannya dengan aturan yang baku. Walaupun demikian, hasil uji Post Hoc menunjukkan hasil yang tidak signifikan antara lima kategori kegiatan ekstrakurikuler yang artinya tidak ada kategori kegiatan ekstrakurikuler yang memiliki karakter disiplin yang lebih tinggi dibandingkan kategori kegiatan ekstrakurikuler yang lain karena skor total karakter disiplin antar partisipan dalam lima kategori kegiatan ekstrakurikuler tidak jauh berbeda.

Karakter penghargaan dan tanggung jawab tidak memiliki perbedaan yang signifikan dalam kegiatan ekstrakurikuler. Ini menunjukkan bahwa siswa yang terlibat dalam kategori kegiatan ekstrakurikuler yang berbeda memiliki skor karakter penghargaan dan tanggung jawab yang relatif sama. Mengikuti kegiatan ekstrakurikuler memberikan siswa kesempatan mengemban tanggung jawab baru selain tanggung jawabnya sebagai siswa dan membantu dirinya merasa memiliki kompetensi karena kegiatan ekstrakurikuler yang diikuti sesuai dengan minatnya. Hal ini selaras dengan yang disampaikan Rich (1992) bahwa tanggung jawab dapat dibentuk dengan memberikan tanggung jawab baru pada individu dan membantu individu merasa memiliki kompetensi. Ketika individu merasa memiliki kompetensi, ia akan memberikan penghargaan terhadap dirinya yang memicu munculnya penghargaan terhadap orang lain. Nilai mean tertinggi untuk karakter disiplin dan penghargaan terdapat pada kategori olahraga sedangkan nilai mean tertinggi untuk karakter tanggung jawab terdapat pada kategori kelompok akademik. Perry (2002, dalam Feldman \& Matjasko, 
2005) menyatakan bahwa siswa yang terlibat dalam kegiatan olahraga memiliki tingkat penggunaan alkohol yang rendah. Marsh dan Kleitman (2003, dalam Feldman \& Matjasko, 2005) menyatakan bahwa siswa yang terlibat dalam kegiatan olahraga memiliki aspirasi yang tinggi terhadap sekolah dan memiliki waktu lebih banyak dalam mengerjakan tugas. Tingkat penggunaan alkohol yang rendah, aspirasi yang tinggi terhadap sekolah, dan tingkat penggunaan narkoba yang rendah menunjukkan perilaku disiplin siswa yang terlibat dalam kegiatan esktrakurikuler sebagaimana definisi disiplin yang digunakan dalam penelitian ini adalah patuh pada aturan yang berlaku di sekolah, di rumah, dan di masyarakat. Tracy dan Erkut (2002 dalam Feldman \& Matjasko, 2005) menunjukkan adanya hubungan positif antara keterlibatan siswa dalam kegiatan olahraga dengan self esteem siswa.

Self esteem merupakan pandangan keseluruhan individu terhadap dirinya sendiri yang biasa disebut sebagai penghargaan diri (Santrock, 2007). Selfesteem ini membuat seseorang menghargai diri sendiri. Individu yang menghargai dirinya sendiri, maka ia akan memberikan nilai terhadap dirinya, tidak menyakiti diri, tidak tergantung pada orang lain, memiliki kemampuan melawan pengaruh negatif dari peer, dan memperlakukan individu lain secara positif (Lickona, 1991). Adanya hubungan positif antara self esteem dengan keterlibatan siswa dalam kegiatan olahraga menunjukkan penghargaan siswa terhadap dirinya dan penghargaan terhadap orang lain. Kedua hal tersebut merupakan dimensi penghargaan yang dinyatakan oleh Lickona (1991).

Nilai mean tertinggi untuk karakter tanggung jawab ditunjukkan oleh siswa-siswa yang terlibat dalam kategori kegiatan kelompok akademik. Kegiatan ekstrakurikuler ini tidak jauh berbeda dengan aktivitas belajar formal karena menyajikan materi-materi yang berkaitan dengan materi pelajaran. Hanya saja situasinya diduga lebih menyenangkan ketimbang aktivitas belajar formal di sekolah. Konteks tanggung jawab dalam penelitian ini memang lebih mengutamakan tugas dan pilihanpilihan yang dibuat yang terkait dengan tugas siswa sebagai pelajar. Wentzel (1993, dalam Evertson \& Weinstein, 2006) menyebutkan bahwa ada empat tugas siswa, yaitu memperhatikan guru, berpartisipasi aktif saat belajar kelompok, mengerjakan tugas-tugas yang diberikan, dan mempelajari materi yang diberikan.

\section{KESIMPULAN}

Ada tiga kesimpulan yang diperoleh dari penelitian ini, yaitu terdapat perbedaan yangsignifikan antara karakter disiplin dalam kegiatan ekstrakurikuler siswa SMA yang menunjukkan adanya perbedaan karakter disiplin antara partisipan yang berbeda kategori kegiatan ekstrakurikulernya, tidak terdapat perbedaan yang signifikan antara karakter penghargaan dalam kegiatan ekstrakurikuler siswa SMA yang artinya karakter penghargaan yang dimiliki partisipan yang berbeda kategori kegiatan ekstrakurikulernya relatif sama, dan tidak terdapat perbedaan yang signifikan antara karakter tanggung jawab dalam kegiatan ekstrakurikuler siswa SMA yang menunjukkan bahwa karakter tanggung jawab yang dimiliki partisipan yang berbeda kategori kegiatan ekstrakurikulernya relatif sama.

Penelitian ini sudah melihat salah satu aspek dalam sekolah yang berperan dalam perkembangan karakter, yaitu kegiatan ekstrakurikuler. Diharapkan penelitian berikutnya dilakukan dengan melihat aspek lain dalam faktor sekolah, seperti guru, minat terhadap sekolah, dan iklim kelas. Penelitian berikutnya juga dapat menggunakan faktor lain yang memengaruhi karakter, seperti pola asuh, keberadaan model positif, kedekatan dengan orang tua sehingga nantinya dapat terlihat kontribusi dari masing-masing faktor dalam pembentukan karakter. Selain itu, penelitian ini hanya berfokus pada tiga karakter saja padahal ada 18 karakter yang dikembangkan dalam pendidikan karakter di Indonesia oleh Kementerian Pendidikan Nasional. Penelitian berikutnya dapat menggunakan karakter lainnya sebagai variabel yang dikaitkan dengan kegiatan ekstrakurikuler sehingga dapat diketahui gambaran 18 karakter dalam kegiatan ekstrakurikuler di Indonesia. Alat ukur yang dibuat dalam penelitian ini disesuaikan dengan konteks dan tujuan penelitian sehingga untuk penelitian berikutnya yang ingin menggunakan alat ukur ini perlu melakukan uji validitas dan reliabilitas terlebih dahulu dengan menggunakan subyek yang memiliki karakteristik yang sama dengan partisipannya dalam penelitian.

\section{REFERENSI}

Anastasi, A. \& Urbina, S. (1997). Psychological Testing. Upper Sadle River, NJ: Prentice-Hall International, Inc.

Banks, J. B. (2002). Childhood discipline: challenges for clinicians and parents. American family physician, 66(8), 1447-1452. 
Berkowitz, M. W., \& Bier, M. C. (2004). Based character education. The Annals of the American Academy of Political and Social Science, 591(1), 72-85.

Dodson, F. (2006). Mendisiplinkan Anak dengan Kasih Sayang. Jakarta: Gunung Mulia.

Evertson, C. M., \& Weinstein, C. S. (2006). Classroom management as a field of inquiry. Handbook of classroom management: Research, practice, and contemporary issues, 3, 16.

Feldman, A. F., \& Matjasko, J. L. (2005). The role of school-based extracurricular activities in adolescent development: A comprehensive review and future directions. Review of educational research, 75(2), 159-210.

Haricahyono, C. (1995). Dimensi-Dimensi Pendidikan Moral. Semarang: IKIP Semarang Press.

Kemendiknas. (2010). Pedoman Pembinaan Akhlak Mulia Siswa Melalui Kegiatan Ekstrakurikuler. Jakarta: Kementerian Pendidikan Nasional.

Kumar, R. (2005). Research Methodology A Step By Step Guide for Beginners. London: Sage Publication
Lickona, T. (1991). Educating for Character: How Our Schools Can Teach Respect and Responsibility. New York: Bantam.

Mahoney, J., Larson, R., \& Eccles, J. (2005). Organized Activities As Contexts of Development: Extracurricular Activities, After-School, and Community Programs. New Jersey: LEA Publisher

Miller, T. W., Kraus, R. F., \& Veltkamp, L. J. (2008). Character education as a prevention strategy for school-related violence. In School violence and primary prevention (pp. 377-390). Springer, New York, NY.

Park, N. (2004). Character strengths and positive youth development. Academy of Political and Social Science, pg. 41-45.

Rich, D. (1992). Mega Skills. New York: Houghton Mifflin Company.

Santrock, J. (2007). Remaja Edisi 11. Jakarta: Erlangga.

Shockley, K. (2009). Practice dependent respect. The Journal of Value Inquiry, pg. 41-46.

Smith, A. B. (2004). How do infants and toddlers learn the rules? Family discipline and young children. International Journal of Early Childhood, 36(2), 27-41. 